\title{
JUURNAL.RU
}

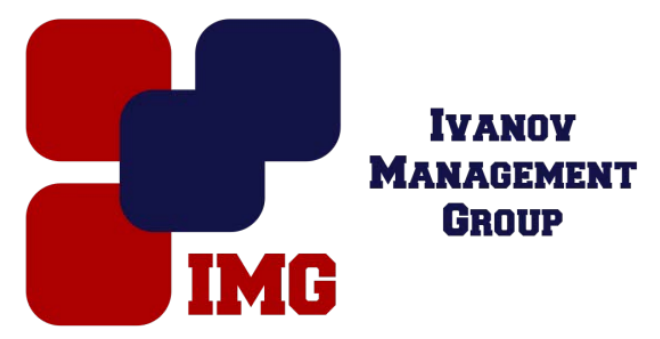

\author{
Акбашева Д. М., Хаиркизова А.А. \\ Северо-Кавказская Государственная Гуманитарно-Технологическая Академия \\ Черкесск, Россия
}

doi: 10.18411/lj-25-12-2016-3-04

idsp 000001:lj-25-12-2016-3-04

\section{Учет затрат по гужевому транспорту}

\begin{abstract}
Аннотация
Гужевой транспорт это вид безрельсового транспорта, в котором в качестве тяги используется сила упряжных животных (лошадей, волов, буйволов,верблюдов,ослов, мулов, оленей, собак и др. ). В зависимости от типа повозки подразделяется на колёсный и санный. От собственно Г. т. Следует отличать, вьючный транспорт, в котором повозка и упряжь отсутствуют, а кладь крепится на вьючном седле или непосредственно на спине животного.
\end{abstract}

Ключевые слова: транспорт,корма

В сельскохозяйственных предприятиях при высокой механизации основных производственных процессов на различных подсобных работах применяется гужевой транспорт. Рабочий скот используется для выполнения таких сельскохозяйственных работ, при котором использование тракторов и другой сельскохозяйственной техники не эффективно. Затраты по содержанию рабочего скота учитываются на отдельном аналитическом счёте 23 «Гужевой транспорт». Учёт затрат ведётся по следующей номенклатуре статей:

1. Расходы на оплату труда.

2. Отчисления на социальные нужды.

3. Средства защиты животных.

4. Корма.

5. Содержание и эксплуатация основных средств.

6. Расходы и услуги.

7. Расходы денежных средств.

8. Прочие затраты.

Основными первичными документами по учёту затрат и выполняемых работ гужевым транспортом являются: формы ПЗ-9.

1) На стоимость израсходованных кормов - ведомость расхода кормов

2) По начисленной заработной плате конюхам и другим работникам книжка бригадира по учёту труда и выполненных работ, которая состоит из 2-х разделов: $3 / 4$ Лист учёта выполненных работ; 3/4 Табель учёта рабочего времени и 
подсчёта заработка на конно-ручных работах;

3) На списание материалов на текущий ремонт и другие хозяйственные нужды на содержание гужевого транспорта - форма 203 АПК.

4) На списание сбруи и других предметов, инструментов, инвентаря.

Аналитический учёт затрат на содержание гужевого транспорта организуется в производственном отчёте по вспомогательным производствам, содержанию и эксплуатации научно-технического производства - форма $18 \mathrm{~B}$, записи в которую производятся на основании первичных документов по учёту затрат и выполняемых работ гужевым транспортом. В производственным отчёте формы 18 В для гужевого транспорта отводится отдельная графа. Синтетический учёт затрат на содержание гужевого транспорта ведётся на счёте 23 « Вспомогательные производства» субсчёт « Гужевой транспорт» в журналеордере 10 АПК, который заполняется на основании данных производственного отчёта формы 18 В. Ведомость расхода кормов Журнал ордер 10 АПК. На сумму услуг, оказанных другими вспомогательными производствами гужевому транспорту Ведомость распределения услуг вспомогательных производств Журнал ордер 10 АПК. На сумму начисленной заработной платы конюхам и начисления на заработную плату Ведомость 78 АПК Журнал ордер 10 АПК. На сумму услуг гужевого транспорта по перевозке материальных ценностей Ведомость распределения услуг гужевого транспорта Журнал ордер 10 АПК. На стоимость услуг гужевого транспорта, оказанных растениеводству Ведомость распределения услуг гужевого транспорта Журнал ордер 10 АПК. Оприходован приплод, полученный от гужевого транспорта Акт на оприходование приплода Журнал ордер 10 АПК. Услуги гужевого транспорта распределяются по потребителям ежемесячно. Единицей работы гужевого транспорта считается 1 рабочий день лошади (коне\дней). Приплод от рабочего скота оценивается в размере стоимости 60 кормо〈дней содержания взрослой лошади[3]. Побочная продукция - навоз - оценивается исходя из нормативных (расчётных) затрат на его уборку и хранение, стоимости подписки и расходов по удалению навоза из ферм и содержанию навозохранилищ. Фактическая clc одного рабочего лошади (коне\дня) определяется путём деления суммы расходов на содержание рабочего скота за исключением затрат на приплод и стоимости побочной продукции на количество конецдней, отработанных рабочим скотом, не включаются дни по самообслуживанию. Расходы по содержанию молодняка рабочего скота в общую сумму затрат по гужевому транспорту не включаются, а учитываются отдельно. Для определения количества рабочих дней среднегодовое поголовье рабочего скота умножают на количество рабочих дней в среднем на голову в год (250 - 240 дней). 


\section{Литература}

1. Верховцев А.В. Положение о составе затрат с постатейными материалами. - М.: ИНФРА-М, 2012 г.

2. Луговой В.А. Учет затрат на производство и реализацию продукции. - М.: Финансы и статистика, 2011 г.

3. Николаев С.А. Особенности учета затрат в условиях рынка, система "директ-костинг". - М.: Финансы и статистика, 2013 г.

4. Г.М. Лисович, И.Ю. Ткаченко, Бухгалтерский учет в сельском хозяйстве и на перерабатывающих предприятиях АПК, -Ростов-на-Дону, Издательский центр «МарТ», -2011 г. 